ISSN : 2721-7876

Gamma-Pi: Jurnal Matematika dan Terapan

Volume 3 Nomor 2 Desember 2021

\title{
ANALISIS FAKTOR-FAKTOR YANG MEMPENGARUHI TINGKAT PENGANGGURAN TERBUKA (TPT) DI KOTA LANGSA
}

\author{
Miranda Olivia ${ }^{1}$, Nurviana ${ }^{2}$ \\ ${ }^{1,2}$ Universitas Samudra; Langsa-Aceh, Telp. (0641) 7445017 Fax (0641) 7445160 Langsa \\ ${ }^{3}$ Jurusan Matematika, Fakultas Teknik, Universitas Samudra \\ e-mail: ${ }^{1}$ mirandaolivia742@gmail.com, ${ }^{2}$ nurviana@unsam.ac.id
}

\begin{abstract}
ABSTRAK
Pengangguran merupakan salah satu permasalahan yang serius dalam ketenagakerjaan. Pengangguran terbuka adalah mereka yang ingin bekerja, sedang berusaha mendapatkan pekerjaan atau mengembangkan pekerjaan tetapi belum berhasil mendapatkannya. Tujuan dari penelitian ini adalah untuk melihat pengaruh laju pertumbuhan penduduk dan garis kemiskinan terhadap Tingkat Pengangguran Terbuka (TPT) di Kota Langsa. Penelitian ini menggunakan data time series tahun 2007-2020 yang diambil dari Badan Pusat Statistik (BPS) Kota Langsa. Metode yang digunakan pada penelitian ini adalah regresi linear beranda, uji asumsi klasik dan uji hipotesis. Model regresi pada penelitian ini adalah regresi linear berganda. Berdasarkan dari hasil pengujian dapat disimpulkan bahwa secara parsial garis kemiskinan berpengaruh signifikan terhadap TPT di Kota Langsa dan secara simultan laju pertumbuhan penduduk dan garis kemiskinan tidak berpengaruh signifikan terhadap TPT di Kota Langsa pada $\alpha=0.05$.
\end{abstract}

Kata kunci : Laju Pertumbuhan Penduduk, Garis Kemiskinan, Tingkat Pengangguran Terbuka, Regresi Linier Berganda, Uji Asumsi Klasik, Uji Hipotesis

\begin{abstract}
Unemployment is one the srious problems in employment. Open unemployment is those who want to work, are trying to get a job but hane not succeeded in getting it. The purpose of this study is to see the effect Gross Regional Domestic Product, population growth rate and poverty line on the open unemployment in langsa City. The study uses time series data from 2010-2020 taken from the Central Statistic Agency of Langsa City. The method used in this study is multiple linear regression, classical assumption test and hypothesis test. The regression model in this study is multiple linier regression. Based on the test results, it can be concluded that partially the poverty line has a significant effect to TPT in Langsa City and simultaneously the population growth rate and poverty line have no significant effect on TPT in Langsa City at $\alpha=0.05$.
\end{abstract}

Keywords: Population growth rate, poverty line, open unemployment rate, multiple linear regression, classical assumption test, hypothesis test.

\section{PENDAHULUAN}

Pengangguran merupakan salah satu permasalahan yang serius dalam ketenagakerjaan yang dialami oleh banyak Negara di dunia karena berhubungan langsung dengan pendapatan masyarakat. Pengangguran merupakan seseorang yang masuk dalam kategori angkatan kerja namun belum mendapat kesempatan untuk bekerja tetapi sedang mencari pekerjaan atau tidak (Mantra, 2013). Menurut Djohanputro (2006), pengangguran terbuka adalah mereka yang ingin bekerja, sedang berusaha mendapatkan pekerjaan atau mengembangkan pekerjaan tetapi belum berhasil mendapatkannya. Menurut Sukirno (dalam Utomo, 2013:7) pengangguran dapat didefinisikan sebagai seseorang yang sudah digolongkan dalam angkatan kerja dan secara aktif sedang mencari pekerjaan pada suatu tingkat upah tertentu, namun tidak dapat memperoleh apa yang diinginkannya. Menurut Sri Budhi (dalam Sirait, 2013) seluruh Negara di Dunia yang dikategorikan dalam Negara maju ataupun Negara berkembang senantiasa mengalami masalah pengangguran, yang membedakannya adalah 
Negara maju mampu memberikan tunjangan kepada warga negaranya yang menganggur, sedangkan Negara Berkembang tidak mampu memberikannya. Nanga (2001) menjelaskan bahwa Edgar Edwards membedakan jenis pengangguran menjadi dua, khususnya yang sering terjadi di Negara berkembang yaitu, setengah pengangguran dan pengangguran terbuka. Adanya pengangguran dapat menyebabkan masalah yang lainnya, seperti terganggunya stabilitas perekonomian dan socialpolitik (Fatmasari, 2018:30-31).

Indonesia masuk kedalam kategori Negara Berkembang yaitu menduduki peringkat ke sembilan dari sepuluh Negara yang termasuk dalam jumlah tingkat pengangguran tetinggi di dunia. Pada bulan agustus 2015 tingkat pengangguran terbuka di Indinesia mencapai 6.18\% (Badan Pusat Statistik, 2018:111).

Provinsi Aceh termasuk dalam sepuluh provinsi dengan angka pengangguran terbanyak. Berdasarkan data dari Badan Pusat Statistik Aceh, tahun 2018 tingkat pengangguran terbuka di Aceh mencapai $6.36 \%$, tahun 2019 tingkat pengangguran terbuka di Aceh menurun menjadi $6.20 \%$ dan pada Agustus 2020 jumlah tingkat pengangguran terbuka di Aceh mengalami peningkatan mencapai $6.59 \%$. Beberapa kabupaten di Aceh memiliki jumlah tingkat pengangguran terbuka yang tinggi, tidak terkecuali kota langsa. Berdasarkan data dari Badan Pusat Statistik Aceh, Kota Langsa termasuk dalam peringkat kedua tertinggi setelah Lhokseumawe. Pada tahun 2019 tingkat pengangguran terbuka di Kota Langsa mencapai $7.70 \%$ dan mengalami peningkatan pada tahun 2020 yaitu $9.75 \%$. Dilihat dari tahun 2007 sampai dengan tahun 2020, persentase tertinggi tingkat pengangguran terbuka di kota langsa berada pada tahun 2009 yaitu $14.74 \%$ dan terendah pada tahun 2017 yaitu $7.03 \%$.

Dalam segi ekonomi mereka yang menganggur tidak memiliki sumber pendapatan untuk memenuhi kebutuhan primer dan sekunder. Hal tersebut berdampak pada masalah sosial, termasuk masalah kriminal dengan motif ekonomi (Djohanputro, 2006).

Penelitian ini bertujuan untuk mengetahui pengaruh dari laju pertumbuhan penduduk dan garis kemiskinan terhadap Tingkat Pengangguran Terbuka (TPT) di Kota Langsa.

\section{METODE PENELITIAN}

Penelitian ini termasuk dalam penelitian kuantitatif. Data yang digunakan pada penelitian ini merupakan data sekunder.
Menurut Sugiyono (2012:141) data sekunder adalah suatu sumber data yang diperoleh dengan membaca, mempelajari dan memahami melalui media yang bersumber dari literature, buku-buku serta dokumen). Menurut Ulber Silalahi (2012:289) data sekunder merupakan suatu data yang dikumpulkan dari tangan kedua atau dari seumber lainnya yang sudah tersedia sebelum penelitian dilakukan. Sumber data dari penelitian ini adalah data yang diambil dan dikumpulkan dari Badan Pusat Statistik (BPS) Kota Langsa. Data yang digunakan berupa data time series dari tahun 2007 2020 yaitu data laju pertumbuhan penduduk dan garis kemiskinan.

Analisis yang digunakan pada penelitian ini adalah analisis regresi linear berganda, uji asumsi klasik dan uji hipotesisi.

\subsection{Analisis Regresi Linear Berganda}

Analisis regresi linear berganda adalah metode yang digunakan pada penelitian ini yang berfungsi untuk melihat pengaruh dari laju pertumbuhan penduduk dan garis kemiskinan terhadap Tingkat pengangguran Terbuka (TPT) di Kota Langsa. Data pada penelitian ini diolah menggunakan SPSS 23. Menurut Arikunto (2013:339) rumus yang digunakan adalah $\mathrm{Y}=\mathrm{a}+\mathrm{bX}+\mathrm{cZ}$, yang kemudian diterjenahkan dalam rumus:

$$
\mathrm{Y}=\mathrm{b}_{0}+\mathrm{b}_{1} \mathrm{X}_{1}+\mathrm{b}_{2} \mathrm{X}_{2}+\mathrm{e}
$$

Keterangan :

$\mathrm{Y}=$ Tingkat Pengangguran Terbuka (TPT)

$\mathrm{b}_{0}=$ Besar pengaruh laju pertumbuhan penduduk dan garis kemiskinan terhadap TPT.

$\mathrm{b}_{1,2}=$ Besarnya variabel $\mathrm{x}$ terhadap variabel $\mathrm{y}$

$\mathrm{X}_{1}=$ Laju Pertumbuhan Penduduk

$\mathrm{X}_{2}=$ Garis Kemiskinan

\subsection{Uji Asumsi Klasik}

Uji asumsi klasik yang digunakan pada penelitian ini yaitu uji normalitas menggunakan metode kolmogov-smirnov dengan dasar pengambilan keputusan jika nilai Asymp. Sig.(2tailed) $>0.05$ maka data berdistribusi normal.

Uji multikolinearitas, uji ini digunakan untuk mengetahui adanya kolerasi atau hubungan antar variabel menggunakan VIF. Jika nilai VIf < 10 maka terbebas dari multikolinearitas. 
Uji heterokedastisitas, uji heteroskedisitas digunakan untuk mengetahui ada atau tidaknya penyimpangan dalam asumsi klasik dan uji autokolerasi

Uji Autokolerasi bertujuan untuk melihat adanya korelasi atau hubungan antara variabel independen dengan variabel dependen. Untuk melihat adanya autokolerasi digunakan uji Durbin Watson (DW) dengan melihat letak nilai regresi. Dasar pengambilan keputusan uji autokolerasi Durbin Watson yaitu :

1. Jika DW (Durbin Watson) $<\mathrm{dL}$ atau DW > (4-dL) maka hipotesis nol ditolak, yang berarti terdapat autokolerasi.

2. Jika DW (Durbin Watson) berada diantara dU dan (4-dU) maka hipotesis nol diterima, yang berarti tidak ada autokolerasi.

3. Jika DW (Durbin Watson) berada diantara dL dan dU atau diantara (4dU) dan (4-dL) maka tidak menghasilkan keputusan yang pasti. Untuk mengatasinya kita dapat melakukan uji runs test.

Untuk mengetahui nilai dU (batas atas) dan $\mathrm{dL}$ (batas bawah) pada tabel Durbin Watson dapat dilihat berdasarkan nilai $\mathrm{k}$ (jumlah variabel independen) dan n (jumlah sampel).

\subsection{Uji Hipotesis}

Uji hipotesis yang digunakan pada penelitian ini adalah uji parsial (uji t), uji t berfungsi untuk menerangkan signifikasi pengaruh antar variabel independen terhadap variabel dependen.Jika nilai Sig $<0.05$ maka $\mathrm{H}_{0}$ ditolak dan $\mathrm{H}_{1}$ diterima.

Uji simultan (uji f), uji ini digunakan untuk mengetahui pengaruh secara simultan (bersamaan) antar variable dependen terhadap variabel independennya

Uji determinasi $\mathrm{R}^{2} \quad \mathrm{Uji}$ Determinasi $\mathrm{R}^{2}$ digunakan untuk mengukur kemampuan variabel independen dalam menerangkan variabel dependennya.

\section{HASIL DAN PEMBAHASAN}

\subsection{Analisis Regresi Linear Berganda}

Berdasarkan koefisien regresi maka persamaan yang didapat adalah :

$$
\mathrm{Y}=1568.675+1.406 \mathrm{X} 1-2.823 \mathrm{X} 2
$$

Nilai koefisien laju pertumbuhan penduduk adalah 1.406 yang berarti setiap kenaikan 1\% laju pertumbuhan penduduk akan menambah Tingkat Pengangguran Terbuka (TPT) sebesar $1.406 \%$. Nilai koefisien garis kemiskinan sebesar -2.823 dapat diartikan bahwa setiap penambahan jumlah garis kemiskinan, Tingkat Pengangguran Terbuka (TPT) akan menurun sebesar $-2.823 \%$

\subsection{Uji Asumsi Klasik}

Hasil uji normalitas menggunakan metode kolmogrof-smirnov diketahui bahwa nilai sig.(2tailed) sebesar $0.200>\alpha 0.05$ yang berarti data berdistribusi normal.

Berdasarkan hasil uji multikolinearitas variabel laju pertumbuhan penduduk dan garis kemiskinan bebas dari multikolinearitas dengan nilai VIF sebesar $1.075<10$.

Hasil dari uji heteroskedastisitas menggunakan scatter plot diketahui bahwa titik tersebar secara acak diatas atau dibawah angka nol sumbu $\mathrm{Y}$ dan tidak membentuk pola tertentu, maka pada metode regresi ini tidak terjadi heteroskedastisitas.

Dalam uji autokolerasi diketahui bahwa nilai DW (Durbin Watson) $=1.539$. Berdasarkan cara pengambilan nilai dU dan dL pada tabel Durbin Watson maka diketahui nilai dU $=1.5507$ dan (4$\mathrm{dU})=2.450$. Maka dapat disimpulkan bahwa nilai DW berada diantara dU dan (4-dU) yaitu $1.550<$ 1.539 .

\subsection{Uji Hipotesis}

Uji parsial (uji t) digunakan untuk mengetahui pengaruh antara variabel bebas $\mathrm{X}$ terhadap variabel terikat $\mathrm{Y}$.

Tabel 1. Hasil Uji Parsial (Uji t)

Variabel Koefisien Sig Hasil

(B)

\begin{tabular}{lccc}
$\begin{array}{l}\text { Laju } \\
\text { pertumbuhan }\end{array}$ & 1.406 & 0.052 & $\begin{array}{c}\mathrm{H}_{0} \text { tidak } \\
\text { ditolak }\end{array}$ \\
penduduk & & & \\
\hline $\begin{array}{l}\text { Garis } \\
\text { kemiskinan }\end{array}$ & $-2.823 \mathrm{E}-5$ & 0.005 & $\mathrm{H}_{0}$ \\
ditolak
\end{tabular}


Berdasarkan tabel 1, diketahui nilai signifikan variabel laju pertumbuhan penduduk $\left(\mathrm{X}_{1}\right)$ adalah 0.052 , maka sig $>0.05$ artinya $\mathrm{H}_{0}$ tidak ditolak. Dapat disimpulkan bahwa laju pertumbuhan penduduk tidak berpengaruh signifikan terhadap tingkat pengangguran terbuka $(\mathrm{Y})$. Untuk variabel garis kemiskinan $\left(\mathrm{X}_{2}\right)$ nilai sig 0.005 , berarti sig < 0.05 , maka $\mathrm{H}_{0}$ ditolak. Jadi kesimpulannya adalah garis kemiskinan berpengaruh signifikan terhadap Tingkat Pengangguran Terbuka (Y).

Pada uji simultan (uji f) nilai signifikan sebesar 0.012 , maka sig > 0.05 artinya $\mathrm{H}_{0}$ diterima dan menolak $\mathrm{H}_{1}$. Dapat disimpulkan bahwa variabel laju pertumbuhan penduduk $\left(\mathrm{X}_{1}\right)$ dan garis kemiskinan $\left(\mathrm{X}_{2}\right)$ secara simultan (bersama) tidak berpengaruh signifikan terhadap tingkat pengangguran terbuka (Y).

Berdasarkan hasil regresi diperoleh nilai $\mathrm{R}^{2}$ sebesar 0.554, maka variabel laju pertumbuhan penduduk dan garis kemiskinan hanya mempengaruhi Tingkat Pengangguran Terbuka (TPT) sebesar $55.4 \%$ dan sisanya $44.6 \%$ ada pada variabel lain yang tidak disebutkan pada model.

\section{KESIMPULAN DAN SARAN}

Berdasarkan hasil analisis maka dapat disimpulkan bahwa :

1. Laju pertumbuhan penduduk tidak berpengaruh signifikan terhadap tingkat pengangguran terbuka

2. Garis kemiskinan berpengaruh signikan terhadap Tingkat Pengangguran Terbuka (TPT)

3. Kedua variabel yaitu laju pertumbuhan penduduk dan garis kemiskinan tidak berpengaruh signifikan terhadap Tingkat Pengangguran Terbuka (TPT).

Adapun saran dari penulis yaitu, untuk pengembangan lebih lanjut terhadap penelitian ini adalah dengan mengganti atau menambahkan variabel bebas dan membandingkan hasil penelitian regresi linier berganda dengan metode lainnya.

\section{DAFTAR PUSTAKA}

Arikunto, Suharshimi. Prosedur Penelitian. Jakarta : Rineka Cipta. 2013.

Badan Pusat Statistik. 2018. Statistik Indonesia 2018. Jakarta: Badan Pusat Statistik.
Badan Pusat Statistik (BPS) Kota Langsa. Diperoleh dari https://langsakota.bps.go.id/ .

Djohanputro dan Bramantyo. 2006. Prinsip-Prinsip Ekonomi Makro. Jakarta:PM.

Fatmasari, Y. 2018. Pengaruh PDRB, Pendidikan, dan Pengangguran terhadap Kemiskinan di Jawa Timur Tahun 2006-2015. Universitas Brawijaya.

Mantra, I. B. 2013. Demografi Umum. Yogyakarta : Pustaka Belajar.

Nanga,M. 2001. Makro Ekonomi: Teori, Masalah Dan Kebijakam Edisi Perdana. Jakarta: Raja Rafindo Persada.

Prasanti, T, A., Puriandri, T., dan Rusjiono, A. 2015. Aplikasi Regresi Data Panel untuk Pemodelan Tingkat Pengangguran Terbuka Kabupaten/Kota di provinsi Jawa tengah. Jurnal Gaussian, 4(3) : 687-696.

Putri, D, A., dan Subroto, W,T. 2016. Analisis Beberapa Faktor yang Mempengaruhi Tingkat Pengangguran Terbuka di jawa Timur Tahun 2003-2014. Jurnal Pendidikan Ekonomi, 1(1) : 1-8.

Setiawan, J., Saleh, M., dan Yulianti, L. 2017. Analisis Faktor-Faktor yang Mempengaruhi Tingkat Pengangguran di Provinsi jawa Timur Tahun 2009-2015. Jurnal Ekuilibrium, 2017, 2(1) ; 31-37.

Setyaningrum, Suprapti, dkk. 2020. Faktor-faktor yang mempengaruhi Tingkat Pengangguran Terbuka di Provinsi Jawa Tengah Tahun 2012 - 2019. Jurnal Studi Bisnis dan Administrasi. Vol. 3 No. 2.

Sugiyono. 2012. Memahami Penelitian Kualitatif. Bandung: ALFABETA.

Sugiyono. 2017. Metode Penelitian Kuantitatif, Kualitatif dan $R \& D$. Alfabeta: Bandung. 
Sirait, Novlin dan Marhaeni, A A I N. 2013. Analisis Beberapa Faktor yang Berpengaruh Terhadap Jumlah Pengangguran Kabupaten/Kota Di Provinsi Bali. E Jurnal EP Unud,(Online),Vol. 2(2) Hal. 108-18.

Ulber Silalahi. 2012. Metode Penelitian Sosial. Bandung: PT. Refika Aditama.

Utomo, F. W. 2013. Pengaruh Inflasi dan Upah Terhadap Pengangguran Di Indonesia Periode Tahun 1980-2010. Jurnal Ilmiah Mahasiswa FEB Universitas Brawijaya, I(2), 1-7. 